\title{
THE SOROPTIMIST CLUB IN KALMAR GOES FOR WATER
}

\author{
Banna Thioiboi \\ Soroptimist Club, Kalmar
}

\begin{abstract}
Drinking water is still a big problem in many African countries. The Soroptimist club of Kalmar started therefore in 2008 to finance different water projects in Mali, in West Africa, in order to make water accessible for women who have to walk several kilometers a day in order to get some water. Thanks to the wells we have financed the women can now plant fruit trees and sell the products. The money goes to school fees for their children and to healthcare.
\end{abstract}

\section{BACKGROUND}

\section{Soroptimist International}

Soroptimist International is a vibrant, dynamic organization for today's professional and business women. We are committed to a world where women and girls together achieve their individual and collective potential, realize aspirations and have an equal voice in creating strong, peaceful communities worldwide. It was in 1948 that Soroptimist International, a worldwide organization for professional and business women started in Sweden. The principles of the organization are based on awareness, advocacy and action. There are about 63 Soroptimist clubs in Sweden. Mission Soroptimists inspire action and create opportunities to transform the lives of women and girls through a global network of members and international partnerships. Our aim is also to advocate for human rights, high ethic, gender issues, development and peace via international goodwill, cooperation and friendship. We reach these goals by supporting national and international projects and by using our network. Togetherness and friendship are also very important in our clubs. As a Soroptimist member, you can join any Soroptimist club in the world and can hence meet other "sisters" from other countries.

\section{The Soroptimist club of Kalmar}

The Soroptimist club in Kalmar started in 1977 and many of our actual members have been member since the very beginning. We are about thirty members and meet once a month in order to discuss and evaluate our different projects. One of the biggest ones has been the financing of different project $\mathrm{s}$ in Mali.

\section{Our project in Mali}

Millions of African still don't have access to drinking water. It means that women in for example Mali, in West Africa must go kilometers every day, in order to fetch some water. But thanks to the cooperation between the Soroptimist Club of Kalmar and the Club Espoir de Bamako in Mali, we have been able to finance wells in three villages where the women can 
today get water where they live. Besides, these wells make it possible to plant fruit trees and sell the products in different markets. The money they get goes to school fees and better healthcare. We have financed four projects and are about to finance the fifth one. We have so far paid 150000 Swedish crowns. The money comes from different events that the Soroptimst Club in Kalmar has arranged the last years and even thanks the cooperation between our club and other Soroptimist clubs in Sweden and in Europe.

\section{Future plans}

Our goal is to continue to work with more projects, in different countries. We do believe that we can make some difference by supporting different projects. Our next move is to work in the domain of democracy, gender issues and education. 